\title{
Response of Bread Wheat (Triticum aestivum L.) to Sulfur Fertilizer Rate Under Balanced Fertilization at Basona Warena District of North Shewa Zone of Amhara Region, Ethiopia
}

Shawl Assefa ( $\sim$ shawelasefa@gmail.com )

Amhara Regional Agricultural Institute

\section{Beza Shewangezaw}

Amhara Regional Agricultural Research Institute, Debre Berhan Agricultural Research Center kenzemed kassie

Amhara Regional Agricultural Research Institute, Debre Berhan Agricultural Research Center

\section{Research}

Keywords: Balanced, Cambisols, S, Vertisols

Posted Date: July 17th, 2020

DOI: https://doi.org/10.21203/rs.3.rs-36084/v1

License: (c) (1) This work is licensed under a Creative Commons Attribution 4.0 International License.

Read Full License

Version of Record: A version of this preprint was published at Communications in Soil Science and Plant Analysis on November 12th, 2020. See the published version at https://doi.org/10.1080/00103624.2020.1845361. 


\section{Abstract}

Background: Sulphur is becoming an important limiting nutrient to agricultural production in Ethiopian soil. Bread wheat is one of the most important cereal crops produced and consumed in Ethiopia.

Declining soil fertility is one of the major factors that accounts for low productivity of wheat in Ethiopia which is caused by soil erosion, continuous cropping of same land year after, deforestation, depletion of organic matter is the main challenge not only to wheat production

Methods: The field experiment was conducted for consecutive three years $(2013 / 14-2015 / 16)$ to evaluate effects of $S$ levels on yield and yield components of bread wheat grown on two soil types (Cambisols and Vertisols), North Central of Ethiopia. An experiment consisting of six levels $S(0,10,20,30,40$ and $50 \mathrm{~kg}$ $\mathrm{ha}^{-1}$ ) laid out in RCB design with three replications.

Results: Results revealed that, yield components were not affected by different levels of $S$ while, yield of wheat were significantly affected by $S$ in both soil types. $S$ applied on cambisols at 30 and $40 \mathrm{~kg} \mathrm{ha}^{-1}$ increased grain yield (GY) of wheat by 9.0 and $10.1 \%$ over control respectively. The corresponding increases on Vertisols were 8.0 and $10.0 \%$ over control respectively. Application of 10 and $30 \mathrm{~kg} \mathrm{~S} \mathrm{ha}^{-1}$ produced the highest MMR (4913.31 and 1277.24\%) respectively.

Conclusions: The current finding presents additional evidence to research claims that $S$ is becoming a limiting nutrient in some Ethiopian soils. Application of 10 and $30 \mathrm{~kg} \mathrm{~S} \mathrm{ha}^{-1}$ are found to be the most economically feasible treatments for bread wheat production in Cambisols and Vertisols of the district respectively.

\section{Background}

Bread wheat (Triticum aesativum L.) is one of the most important cereal crops produced and consumed in Ethiopia. It stands third among cereals in terms of area cultivated annually and grain production next to barley and tef (CSA, 2016). Traditionally, wheat grains are used to prepare household bread, beverage and pancake. It is also processed in factories to produce flour for commercial production of bread for consumers in cities and towns. Despite its importance and growing demand for bread wheat in Ethiopia, its production and productivity are desperately very low. The current average productivity of wheat is below $3 \mathrm{t} \mathrm{ha}^{-1}$ (CSA, 2016) despite its potential productivity greater than 5tha-1 (Birhan et al., 2016). Consequently, the country imports large amounts (30-50\% of total annual demand) wheat grains every year from abroad to meet domestic demand (Minot et al., 2015) which has grave consequence on foreign currency reserve of the country.

Declining soil fertility is one of the major factors that accounts for low productivity of wheat in Ethiopia (Yesuf and Duga, 2000; Amsal et al., 1997) which is caused by soil erosion, continuous cropping of same land year after, deforestation, depletion of organic matter is the main challenge not only to wheat production but also to the production of all crops (Birhan et al., 2016). It is an issue of great concern in 
Ethiopia as soil nutrient depletion is becoming severe and severe with time since little efforts are being made to reverse the problem.

There were several occasions whereby the yields of crops produced per unit area were increased by more than $100 \%$ in many areas of Ethiopia (Kelsa et al., 1992). For example, Gebreyes (2008) reported that application of $92 \mathrm{~kg} \mathrm{~N} \mathrm{ha}^{-1}$ increased grain yield of wheat by $185 \%$ over the control in central Ethiopia. Thus, due to dramatic positive impact, there was a steady increase in annual fertilizer consumption from $14000 \mathrm{mt}$ in 1974/75 to 500, $000 \mathrm{mt}$ in 2010 (IFPRI, 2012). However, crop yield gain due to $\mathrm{N}$ and $\mathrm{P}$ fertilizer application is declining over time despite steady increases in fertilizer consumption in Ethiopia (IFPRI, 2010). Declining crop yield responses to $\mathrm{N}$ and $\mathrm{P}$ fertilizers is attributed to decreasing soil organic matter (SOM) content (IFPRI, 2010). Moreover, depletion of other nutrients in addition to $\mathrm{N}$ and $\mathrm{P}$ could be additional factor for decreasing response of crops to $\mathrm{N}$ and $\mathrm{P}$ fertilizers (Wassie and Tekalign, 2013).

Sulphur (S) could be one of the most likely limiting nutrients in Ethiopia soils. Sulphur is one the plant essential nutrients required for their growth and developments and a building block of protein, key ingredient in the formation of chlorophyll (Duke and Reisenaue, 1986). It plays important role in protein synthesis as it is the component of two essential amino acids called cysteine and methionine. It is also a key component of many enzymes in plants. For instances, the $S$ is important component of nitrogenase enzyme, an enzyme that fixes atmospheric nitrogen in legume-rhizobia biological nitrogen fixation system. Sulphur also interacts with nutrients in soils and the interaction could be positive or negative depending on several factors. For example, Aulakh and Chhibba (1992) observed enhanced root uptakes of $\mathrm{P}$ and $\mathrm{S}$ when both nutrients were supplied at low rates. Increased uptake and assimilation of $\mathrm{N}$ by crops has reported by with adequate than low supply of S (Kumar et al., 2012). Thus, deficiency of $S$ in soils will have adverse consequences on protein synthesis, biological nitrogen fixation, chlorophyll synthesis, enzyme activity etc. ultimately compromising yield and quality of crops. It has been reported that $S$ deficient plants exhibits reduced plant height and stunted growth, reduced tillers, spikelets and delayed maturity. Sulfur deficient plants are shown to be less resistance under stress conditions (Doberman and Fairhurst, 2000).

In this regards, emerging research evidences are showing that $S$ one of the nutrients becoming deficient in some Ethiopian soils limiting crop production. For instance, Assefa (2016) studied the response of wheat to $S$ application on 18 sites reported that wheat significantly responded to $S$ fertilizer application in $72 \%$ of experimental sites. He further reported that soils of responding sites had $\mathrm{S}$ content below critical level (11-13 $\left.\mathrm{mg} \mathrm{kg}^{-1} \mathrm{SO}_{4}{ }^{-2}-\mathrm{S}\right)$ for optimum production of wheat.

However, the current assertion that $S$ is becoming nutrient in some Ethiopia soils is based on results of only few experiments and thus it can't be conclusive and definitive that Ethiopian soils are deficient in S. Thus, further research is needed to be done to verify the existing claims that $\mathrm{S}$ limiting in Ethiopian soils in different soil types. In this regard, there is little or no information so far on the response of wheat to $S$ application in Basona worena district of north Shewa, Ethiopia. Thus, experiment was conducted to determine effects of $S$ application under balanced fertilization on the growth, yield components and yield 
of wheat and to determine economic feasibility of $S$ fertilizer application of wheat grown on famers' at Basona werna District under two soil types of Vertisols and Cambisols.

\section{Materials And Methods \\ Description of the study areas}

The experiment was conducted for 3 consecutive years (2013/14-2015/16) cropping season on two locations at Goshebado (Vertisols) and Gudoberet (Cambisols) about 147 and 172 km northwest, and East of Addis Ababa respectively. Geographically, the field experiment was conducted at a range of $09^{0}$, $43^{\prime}, 58.4^{\prime \prime}$ to $09^{\circ}, 44^{\prime}, 45.8^{\prime \prime} \mathrm{N}$ and $039^{\circ}, 25^{\prime}, 39.1^{\prime \prime}$ to $039^{\circ}, 27^{\prime}, 29.4^{\prime \prime} \mathrm{E}$ and an altitude of 2796 to 2990 m.a.s.l at Goshebado and $09^{\circ}, 46^{\prime}, 21.2^{\prime \prime}$ to $N 09^{\circ}, 47^{\prime}, 06.5^{\prime \prime}$ and $039^{\circ}, 39^{\prime}, 37.3^{\prime \prime}$ to $039^{\circ}, 40^{\prime}, 08.5^{\prime \prime} \mathrm{E}$ and an altitude of 2914 to 3043 m.a.s.l at Gudoberet. The study locations (soil types) and the district as a whole are characterized by having a uni-modal rainfall pattern and receives an average annual rainfall of $921.2 \mathrm{~mm}$. Vertisols is the dominant soil type that the experiment conducted at Goshebado and Cambisols at Gudoberet. Major crops grown in both locations; wheat, Barley, lentil, faba bean, and chickpea, field pea and grass pea in decreasing orders of area cultivated under these crops.

\section{Soil sampling and analyses}

After selecting the experimental sites, pre-planting soil samples were collected from each site for the analyses of selected physicochemical properties. Composite soil samples were taken from each site from a depth of $0-20 \mathrm{~cm}$ using augur randomly from 15 spots by walking in a zigzag pattern. After thoroughly mixing the composite samples, $1 \mathrm{~kg}$ of sub-sample was taken and brought to Debre Birhan agricultural research Centre soil laboratory where it was air dried and grounded to pass $2 \mathrm{~mm}$ mesh sized sieve.

The processed samples were analysed for texture following by Bouyoucous hydrometer method (Bouyoucous, 1962). The $\mathrm{pH}$ of the soil was measured using $\mathrm{pH}$-water method by making soil to water suspension of $1: 2.5$ ratio and was measured using a $\mathrm{pH}$ meter. The soil $\mathrm{OC}$ content was determined by wet digestion method (Walkley and Black, 1934). Total nitrogen (TN) was determined by using the modified micro Kjeldhal method (Cottenie, 1980), available P (ava. P) was analysed by using Olsen's calorimetric method as described by Olsen et al. (1954).

\section{Treatments, design and experimental procedure}

The experiment consisting of six levels of $S\left(0,10,20,30,40\right.$ and $\left.50 \mathrm{~kg} \mathrm{ha}^{-1}\right)$ accompanied by $69 \mathrm{P}_{2} \mathrm{O}_{5}, 80 \mathrm{k}_{2} \mathrm{O}, 92 \mathrm{~N}$ and micronutrients $\left(2 \mathrm{Zn}, 2 \mathrm{Cu}\right.$ and $\left.0.5 \mathrm{~B} \mathrm{~kg} \mathrm{ha}{ }^{-1}\right)$ and was laid out in RCB design with three replications. Calcium sulphate $\left(\mathrm{CaSO}_{4}\right)$, Borax, Zinc Sulphate and Triple super phosphate (TSP) were used as S, B, Zn and P sources respectively. The test crop, wheat variety, Diglo was planted in a unit 
plot size of $3.6 \times 3.4 \mathrm{~m}$ with row spacing of $20 \mathrm{~cm}$ apart at a rate of $131.25 \mathrm{~kg} \mathrm{ha}^{-1}$. The whole doses of $\mathrm{CaSO}_{4}, \mathrm{KCl}$ and TSP fertilizers were applied as basal in both sides of rows just before planting as per the treatment. The Urea- $\mathrm{N}$ was split in which one half of $\mathrm{N}$ was applied at planting and the remaining one half was applied one month after planting and after weeding. Micronutrients $(\mathrm{Zn}, \mathrm{B}$, and $\mathrm{Cu})$ in the form of ZnS04, Borax and CuS04 respectively was applied foliar mode two times at tillers developments stage of the crops. All agronomic management of the trails were done as per the specific recommendation for the crop.

\section{Data analysis}

The collected data were subjected to statistical analysis of variance (ANOVA) and carried out using SAS software program using SAS version 9.3 (SAS institute Inc, 2011). Normality and homogeneity of variance were checked and Combined analysis for the 3 years were done by using the procedure of SAS software version 9.3 (SAS, 2011). Mean comparisons were done by Least Significant Difference (LSD) according to the procedure of Gomez and Gomez (Gomez KA and Gomez AA, 1984) at the $5 \%$ level.

\section{Economic analyses}

Partial budget analysis was done to determine economic feasibility of $S$ fertilizer for bread wheat production around the study areas following procedures described in CIMMYT (1998). The mean grain and straw yield data of wheat were employed in the analyses. Furthermore, the grain and straw yield obtained from each treatment were adjusted down by $10 \%$ in order to narrow the possible yield gap that may happen due to difference in field management. The average prices of relevant inputs required to do the partial budget analyses were collected from different sources. The average prices of relevant inputs required to do the partial budget analyses were collected from different sources. Accordingly, the prices of gypsum fertilizer during planting of this experiment was collected from Debire Birhan town. Accordingly, price of gypsum was 1.2 Ethiopian birr (ETB) $\mathrm{kg}^{-1}$. The field prices of grain and straw yield at the district local market around the study area was used. Accordingly, prices of grain and straw yield of wheat were 10.5 and $2.4 \mathrm{ETB} \mathrm{kg}^{-1}$ respectively.

\section{Result And Discussion}

\section{Soil physical and Chemical properties}

Pre-planting soil analyses data of selected physicochemical properties of samples collected from experimental locations at Goshebado (Vertisols) and Gudoberet (Cambisols) are summarized in Table 1. The soils of Goshebado and Gudoberet was belonging to clay textural class. Goshebado soil has soil reaction is ranged from moderately acidic to neutral whereas the soil of Gudoberet is ranged from slightly acidic to neutral reaction (Murphy, 1968). The OC and TN content of both soil types are in low categories according to Tekalign (1991). The available P content of Gudoberet (Cambisols) is medium range while 
at Goshebado (Vertisols) is ranged from very low to low categories (Olsen et al., 1954). The available soil $P$ value for crop production and yet it is far lower than the critical soil available $P$ value established for some Ethiopian soils which is $8 \mathrm{mg} \mathrm{kg}^{-1}$ (Tekalign and Haque, 1991).

Table 1

Soil physico-chemical properties of the study sites across years

\begin{tabular}{|lllllll|}
\hline Parameters & \multicolumn{3}{l}{ Cambisols } & \multicolumn{5}{l|}{ Vertisols } \\
\cline { 2 - 7 } & $\mathbf{2 0 1 4}$ & $\mathbf{2 0 1 5}$ & $\mathbf{2 0 1 6}$ & $\mathbf{2 0 1 4}$ & $\mathbf{2 0 1 5}$ & $\mathbf{2 0 1 6}$ \\
\hline pH (1:2.5) ratio & 6.2 & 6.7 & 6.5 & 7.15 & 7.2 & 5.9 \\
\hline Av. P (ppm) & 5.04 & 7.76 & 6.06 & 8.7 & 0.12 & 0.42 \\
\hline TN (\%) & 0.11 & 0.08 & 0.08 & 0.08 & 0.06 & 0.06 \\
\hline OC (\%) & 1.11 & 0.90 & 0.91 & 0.83 & 0.70 & 0.70 \\
\hline C:N & 10.47 & 10.81 & 10.79 & 11.0 & 11.5 & 11.48 \\
\hline Sand (\%) & 12 & 16 & 30 & 8 & 12 & 16 \\
\hline Clay (\%) & 56 & 56 & 42 & 70 & 68 & 70 \\
\hline Silt (\%) & 32 & 28 & 28 & 22 & 20 & 14 \\
\hline Textural Class & clay & clay & clay & clay & clay & clay \\
\hline
\end{tabular}

Table 2

Mean squares for sources of variation

\begin{tabular}{|c|c|c|c|c|c|c|c|}
\hline \multirow[t]{2}{*}{ Parameters } & \multicolumn{7}{|c|}{$\begin{array}{l}\text { Mean squares for sources of variation with respective degrees of freedom in } \\
\text { parenthesis }\end{array}$} \\
\hline & $S(5)$ & $Y(2)$ & SL(1) & $\begin{array}{l}\text { Rep in } \\
\text { SL(2) }\end{array}$ & $Y * S(10)$ & $\begin{array}{l}S L * S \\
(5)\end{array}$ & $\begin{array}{l}\text { Error } \\
\text { (82) }\end{array}$ \\
\hline $\mathrm{PH}$ & $5.9^{\text {ns }}$ & $1267.7^{\star *}$ & $6198.6^{* *}$ & 20.2 & $7.1^{\mathrm{ns}}$ & $4.2^{\text {ns }}$ & 19.0 \\
\hline SPL & $0.05^{\text {ns }}$ & $13.30^{* *}$ & $32.34^{* *}$ & 0.24 & $0.03^{\mathrm{ns}}$ & $0.04^{\mathrm{ns}}$ & 0.24 \\
\hline NT & $0.13^{\text {ns }}$ & $1.91^{\star *}$ & $97.28^{* *}$ & 0.60 & $0.10^{\mathrm{ns}}$ & $0.15^{\mathrm{ns}}$ & 0.26 \\
\hline FT & $0.2^{\text {ns }}$ & $1.6^{* *}$ & $124.8^{* *}$ & 0.4 & $0.1^{\mathrm{ns}}$ & $0.1^{\mathrm{ns}}$ & 0.23 \\
\hline GY & $209145^{\star}$ & $10193262^{* *}$ & $50311170 * \star$ & 101528 & $11803^{\mathrm{ns}}$ & $\begin{array}{l}802 \\
41^{\text {ns }}\end{array}$ & 779140 \\
\hline STY & $515449 *$ & $18621526^{\star \star}$ & $57295361^{\star * *}$ & 19410 & $62392^{\mathrm{ns}}$ & $42210^{\text {ns }}$ & 2049051 \\
\hline
\end{tabular}




\section{Effect on growth and yield components of Wheat}

On both soil types, growth and yield components of bread wheat didn't respond significantly (Table 2). Data in Table 3 showed that effects of S on mean growth and yield components of wheat at both Soils types

Table 3

Effect of S on growth and yield components of Wheat at Goshebado (Vertisols) and Gudoberet (Cambisols)

\begin{tabular}{|c|c|c|c|c|c|c|c|c|}
\hline \multirow[t]{2}{*}{ S-rate $\left(\mathrm{kg} \mathrm{ha}^{-1}\right)$} & \multicolumn{4}{|c|}{ Cambisols } & \multicolumn{4}{|c|}{ Vertisols } \\
\hline & $\mathrm{PH}$ & SPL & TN & $\mathrm{FT}$ & $\mathrm{PH}$ & SPL & TN & $\mathrm{FT}$ \\
\hline 0 & 88.4 & 6.3 & 4.9 & 4.8 & 73.5 & 5.4 & 2.9 & 2.7 \\
\hline 10 & 90.6 & 6.4 & 5.1 & 5.0 & 74.4 & 5.4 & 2.9 & 2.6 \\
\hline 20 & 88.8 & 6.5 & 4.7 & 4.7 & 74.5 & 5.3 & 2.9 & 2.6 \\
\hline 30 & 89.2 & 6.5 & 4.9 & 5.0 & 75.4 & 5.4 & 3.1 & 2.8 \\
\hline 40 & 90.0 & 6.4 & 4.8 & 4.8 & 74.0 & 5.2 & 3.0 & 2.8 \\
\hline 50 & 90.1 & 6.5 & 4.9 & 4.9 & 74.5 & 5.4 & 3.2 & 2.9 \\
\hline CV (\%) & 4.3 & 3.5 & 9.2 & 9.7 & 1.8 & 4.1 & 7.4 & 9.1 \\
\hline $\operatorname{LSD}(<0.05)$ & ns & ns & ns & ns & ns & ns & ns & ns \\
\hline
\end{tabular}

\section{Effect on yield of Wheat}

Both grain yield (GY) and straw yield (GY) of wheat were significantly affected by effects of S application in both Cambisols and Vertisols (Table 2). Data in Fig. 2 showed that effects of $S$ on mean Grain and Straw yield of wheat at both Soils types. On Cambisols, increase in S rate up to $30 \mathrm{~kg} \mathrm{~S} \mathrm{ha}^{-1}$ ) had a positive effect on grain and Straw yield of wheat while above $30 \mathrm{~kg} \mathrm{~S} \mathrm{ha}^{-1}$, yield decreased numerically, but not significantly. Application of 20 and $30 \mathrm{~kg} \mathrm{ha}^{-1} \mathrm{~S}$ have significantly increased grain yield by 9.0 and $10.1 \%$ over the control respectively and Straw yield by 10.4 and $105 \%$ over control respectively. Similarly, on Vertisols, 30 and 40 rates have significantly increased grain yield by 8.0 and $10.0 \%$ over control respectively and same treatments increased Straw yield by 10.6 and $9.0 \%$ over control respectively. Generally, application of $S$ on both soils types improve grain and straw yield of bread wheat. These results are in agreement with the finding of Assefa Menna (2016) who studied the response of wheat to $S$ application and reported that wheat significantly responded to $S$ fertilizer application. In another study, Khan et al. 2015) reported that S applied at $20 \mathrm{~kg} \mathrm{ha}^{-1}$ at stem elongation stage 
significantly increased yield of wheat by $28.5 \%$ over untreated control. According to DeRuiter and Martin 2001), wheat yield can be increased up to $42 \%$ due to $S$ fertilizer depending the inherent $S$ level in particular soils.

\section{Effects of Soil and Years}

Results of analyses of wheat response data to over all of the two soils and years are summarized in Table 4. Soils and years have significantly affected PH, SPL, NT, BY, GY and STY of wheat. Accordingly, significantly higher values of these parameters were obtained in Cambisols than Vertisols. Cambisols, GY and STY were higher by 34.9 and $28.3 \%$ over that produced than Vertisols irrespective of treatments. This could be possible be due to better nutrient availability to crop in Cambisols than Vertisols.

Table 4

Overall mean on growth, yield components and yield of wheat across soils and years

\begin{tabular}{|c|c|c|c|c|c|c|c|}
\hline Soil & $\mathrm{PH}$ & SPL & NT & FT & BY & GY & STY \\
\hline Cambisols & $89.5 a$ & $6.4 a$ & $4.9 a$ & $4.8 \mathrm{a}$ & $9061.1 \mathrm{a}$ & $3915.2 a$ & $5145.9 a$ \\
\hline Vertisols & $74.4 \mathrm{~b}$ & $5.3 b$ & $3.0 \mathrm{~b}$ & $2.7 \mathrm{~b}$ & $6239.4 b$ & $2550.2 b$ & $3689.2 b$ \\
\hline LSD (<0.05) & 1.67 & 0.19 & 0.196 & 0.18 & 869.5 & 337.93 & 548.02 \\
\hline \multicolumn{8}{|l|}{ Year } \\
\hline 1 & $75.3 c$ & $5.2 \mathrm{c}$ & $4.2 a$ & $4.0 \mathrm{a}$ & $6807.2 b$ & $2713.6 c$ & $4093.6 b$ \\
\hline 2 & $84.0 \mathrm{~b}$ & $6.1 b$ & $3.9 b$ & $3.9 \mathrm{~b}$ & $7124.9 b$ & $3207.5 b$ & 3917.3b \\
\hline 3 & $86.6 a$ & $6.4 a$ & $3.6 \mathrm{c}$ & $3.6 \mathrm{c}$ & $9018.7 a$ & $3776.9 a$ & $5241.8 a$ \\
\hline LSD (<0.05) & 2.0 & 0.2 & 0.2 & 0.2 & 1064.9 & 413.9 & 671.2 \\
\hline \multicolumn{8}{|c|}{$\begin{array}{l}\mathrm{PH}=\text { plant height }(\mathrm{cm}), \mathrm{SPL}=\text { spike length }(\mathrm{cm}), \mathrm{NT}=\text { number of total tillers plant } \\
\text { plant }^{-1}, \mathrm{FT}=\text { fertile tillers } \\
2014,2=2015,3=2016 .\end{array}$} \\
\hline
\end{tabular}

\section{Economic Analyses}

The results of partial budget analyses data of $S$ fertilizers across two soils are summarized in Table 5 . Accordingly, all treatments produced higher and positive net benefit (NB) relative to the control treatment in both soil types, indicating that feasibility of $S$ fertilizer application for wheat production in the study area. In general, NB from application of S fertilizer produced from Cambisols was higher than Vertisols. Consequently, the highest NB (42884.9 and 27074.7 ETB) was produced by application of S at 30 and $40 \mathrm{~kg} \mathrm{ha}^{-1}$ on Cambisols and Vertisols respectively. When it comes to MRR, the highest value of MRR 
(4913.31 and $1277.24 \%$ ) was produced by S at a rate of 10 and $30 \mathrm{~kg} \mathrm{ha}^{-1}$ from Cambisols and Vertisols respectively.

Table 5

Partial budget analysis of wheat to the study areas

\begin{tabular}{|c|c|c|c|c|c|c|c|}
\hline \multirow[t]{2}{*}{ S-rate $\left(\mathrm{kg} \mathrm{ha}^{-1}\right)$} & \multicolumn{3}{|c|}{ Cambisols } & \multirow[b]{2}{*}{ TVC } & \multirow[b]{2}{*}{ NB } & \multirow[b]{2}{*}{ MRR } & \multirow[b]{2}{*}{ MRR (\%) } \\
\hline & $\begin{array}{l}\text { AGY } \\
\left(\mathrm{kg} \mathrm{ha}^{-1}\right)\end{array}$ & $\begin{array}{l}\text { ASTY } \\
\left(\mathrm{kg} \mathrm{ha}^{-1}\right)\end{array}$ & TGB & & & & \\
\hline 0 & 3635.9 & 4771.9 & 44175.7 & 5334 & 38841.7 & - & - \\
\hline 10 & 3961.6 & 5270.2 & 48302.9 & 5418 & 42884.9 & 49.13 & 4913.31 \\
\hline 20 & 3992.0 & 5323.0 & 48703.2 & 5501 & 43202.2 & 27.11 & 2711.08 \\
\hline 30 & 4062.6 & 5333.9 & 49364.8 & 5584 & 43780.8 & 20.76 & 2075.62 \\
\hline 40 & 3929.6 & 5101.7 & 47610.5 & 5668 & 41942.5 & 10.28 & 1028.38 \\
\hline 50 & 3909.5 & 5174.7 & 47604.8 & 5751 & 41853.8 & 8.22 & D \\
\hline S-rate $\left(\mathrm{kg} \mathrm{ha}^{-1}\right)$ & & Vertisols & & & & & \\
\hline 0 & 2438.1 & 3421.2 & 30153.8 & 6016 & 24137.8 & - & - \\
\hline 10 & 2460.7 & 3666.6 & 30946.1 & 6091 & 24855.1 & 10.56 & 1056.45 \\
\hline 20 & 2502.8 & 3734.1 & 31487.0 & 6166 & 25321.0 & 8.89 & 888.83 \\
\hline 30 & 2649.2 & 3827.0 & 33027.6 & 6241 & 26786.6 & 12.77 & 1277.24 \\
\hline 40 & 2707.3 & 3760.4 & 33390.7 & 6316 & 27074.7 & 10.79 & 1078.95 \\
\hline 50 & 2572.8 & 3726.0 & 32097.6 & 6391 & 25706.6 & 5.18 & D \\
\hline
\end{tabular}

\section{Conclusion And Recommendation}

The results of this experiment revealed that application of $S$ fertilizer has significantly increased yield of bread wheat grown in Cambisols and Vertisols of the study district, northern Shewa, Ethiopia compared to that obtained from unfertilized control. Moreover, the current finding presents additional evidence to research claims that $S$ is becoming a limiting nutrient in some Ethiopian soils which being reported. Maximum yield of wheat was obtained with treatment involving application of $30 \mathrm{~kg} \mathrm{~S} \mathrm{ha}^{-1}$ and $40 \mathrm{~kg} \mathrm{~S}$ ha $^{-1}$ from Cambisols and Vertisols respectively. While, partial budget analysis result revealed that, 10 and $30 \mathrm{~kg} \mathrm{~S} \mathrm{ha}^{-1}$ produced the highest MMR (4913.31 and 1277.24\%) and thus, those treatments are found to 
be economically feasible treatments for bread wheat production in Cambisols and Vertisols of the district of Basona worena respectively.

\section{Abbreviations}

ANOVA: Analysis of variance; BY: CSA: Central Statistical Authority; GY: grain yield; NUG: RCB: randomized complete block; S: Sulfur; STY: Straw yield.

\section{Declarations}

\section{Acknowledgement}

The authors would like to thank to Africa Rising Project, Amhara Agricultural Research Institute and Debre Birhan agricultural research center for their great support sponsoring this research.

\section{Funding}

The study was not receiving any funding from external body

\section{Availability of data and materials.}

The datasets used during the current study are available from the corresponding author on reasonable request.

\section{Authors' contributions}

SA has made significant contribution in conception and designing of the study, soil sample collection, analysis, interpretation and wrote the manuscript and represented as a corresponding author; BS and KK have contributed in assisted in analysis and editing, commenting and suggesting ideas in the manuscript preparation process. And, as a final point all authors read and approved the final manuscript for publication.

\section{Ethics approval and consent to participate}

Not applicable.

\section{Consent for publication}

Not applicable. 


\section{Competing interests}

The authors declare that they have no competing interests.

\section{References}

1. Amsal Tarekegne, Tanner, D.G. and Chanyalew Mandefro. (1997). Effect of cropping sequence and nutrient application on crop parameters during the first three seasons of a wheat Based Long-Term Trial in Central Ethiopia. pp. 685-694. In: Adipala, E., Tenywa, J.S., and Ogenga-Latigo, M.W. (Eds.). Proceedings of African Crop Science Conference 13.

2. Assefa Menna. (2016). Sulphur status of soils and wheat plants in three representative areas of the central highlands of Ethiopia. University of agriculture. Morogoro, Tanzania.162pp

3. Aulakh, M. and Chhibba, I. (1992). Sulfur in soils and response of crops to its application in Punjab, Pakistan. Fert. News, 37: 33-35

4. Birhan Abdulkadir, Sofiya Kassa, Temesgen Desalegn, Kassu Tadesse and Mihreteab Haileselassie. (2016). Soil fertility management studies on wheat in Ethiopia: A review. Eth. J. of Nat. Res. 16:1-2

5. Bouyoucos, G. (1962). Hydrometer method improved for making particle size analysis of soils. Agronomy Journal 54:464-465.

6. CIMMYT (International Maize and Wheat Improvement Center. (1998). From agronomic data to farmer recommendations: An economic workbook. CIMMYT, Mexico.

7. Cottenie, A. (1980). Soil and plant testing as a basis of fertilizer recommendations. FAO soil bulletin 38/2.Food and Agriculture Organization of the United Nations, Rome.

8. CSA (Central Statistical Agency. (2016). Agricultural Sample Survey 2015/2016 (2008

E.C Agricultural Sample Survey. Volume I: Report on area and production of major crops private peasant hol dings, Meher season). Statistical Bulletin 584, Addis Ababa.

9. DeRuiter, J. and Martin, R. (2001). Management of nitrogen and sulphur fertilizers for improved bread wheat (Triticum aestivum L.) quality. New Zealand Journal of Crop and Horticultural Sciences 29:287-299.

10. Dobermann, A. and Fairhurst, T. (2000). Nutrient disorder and nutrient management. Handbook Series. Potash and Phosphate Institute of Canada and International Rice Research Institute. 191p

11. Duke, S. and Reisenauer, H. (1986). Roles and requirements of sulfur in plant nutrition. In: M. A. Tabatabai (ed.): Sulfur in agriculture. Agron.Monogr. No. 27, Am. Soc. Agron., Madison Wisconsin, USA: $123-168$.

12. Gebreyes Gurmu. (2008). Soil Fertility Characterization and Response of Durum Wheat to Nitrogen and Phosphorus Fertilization on Vertisols at Enewari, Northeastern Ethiopia. M.Sc Thesis, Haramaya University, Ethiopia 
13. IFPRI. (2010). Fertilizers and soil fertility potential in Ethiopia: Constraint and opportunities for enhancing the system. IFPRI, Washington DC

14. Kelsa Kena, Tadesse Yohannes and Tesfa Bogale. (1992). Influence of fertilizer and its related management practice on maize grain yield in major maize producing areas of Ethiopia. In: Proceedings of the first national maize workshop of Ethiopia. 5-7 May 1992, Addis Ababa, Ethiopia

15. Khan, R., M. Hussain, S.Z. and Muhammad, Z. (2015). Influence of sulphur and nitrogen on growth, yield and quality of wheat crop grown in Peshawar region of Pakistan. Journal of Global Innovation Agriculture and Social Science 3(4): 124-129.

16. Kumar, R., Singh, V.K., Sharma, R.P., Kumar, A. and Singh, G. (2012). Impact of nitrogen, phosphorus, potash and sulphur on productivity of rice-wheat system in sub-humid region. J. Agric. Physics 12: 84-88.

17. Minot, N., J. Warner, S. Lemma, L. Kassa, A. Gashaw and S. Rashid. (2015). The Wheat Supply Chain in Ethiopia: Patterns, trends, and policy options. International Food Policy Research Institute (IFPRI), Addis Ababa, Ethiopia.

18. Olsen, S.R., Cole, C.V., Watanabe, F.S. and L.A. Dean. (1954). Estimation of available phosphorus in soils by extraction with sodium carbonate. USDA Circular 939: 1-19.

19. SAS. (2012). User's guide, Statistics, Version 9.4 Edition. SAS Inst, Inc., Cary, NC.

20. Tekalign Tadese. (1991). Soil, plant, water, fertilizer, animal manure and compost analysis. Working Document No. 13. International Livestock Research Center for Africa, Addis Ababa

21. Walkley, A. and Black, I. (1934). An examination of Degtjareff method for determining soil organic matter and a proposed modification of the chromic acid titration method. Soil Sci. 37:29-37.

22. Wassie Haile and Tekalign Mamo. (2013). The effect of potassium on the yields of potato and wheat grown on the acidic soils of Chencha and HagereSelam in Southern Ethiopia. International Potash Institute, e-ifc No. 35. http://www.ipipotash.org/en/k-center/e-ifcnewsletter.

23. Yesuf Assen and Duga Debele. (2000). The effect of rate and time of $n$ application on its uptake by bread wheat varieties and soil characteristics of farmers' fields. ethiopian Journal of Natural Resources 2 (2): 137-150.

\section{Figures}




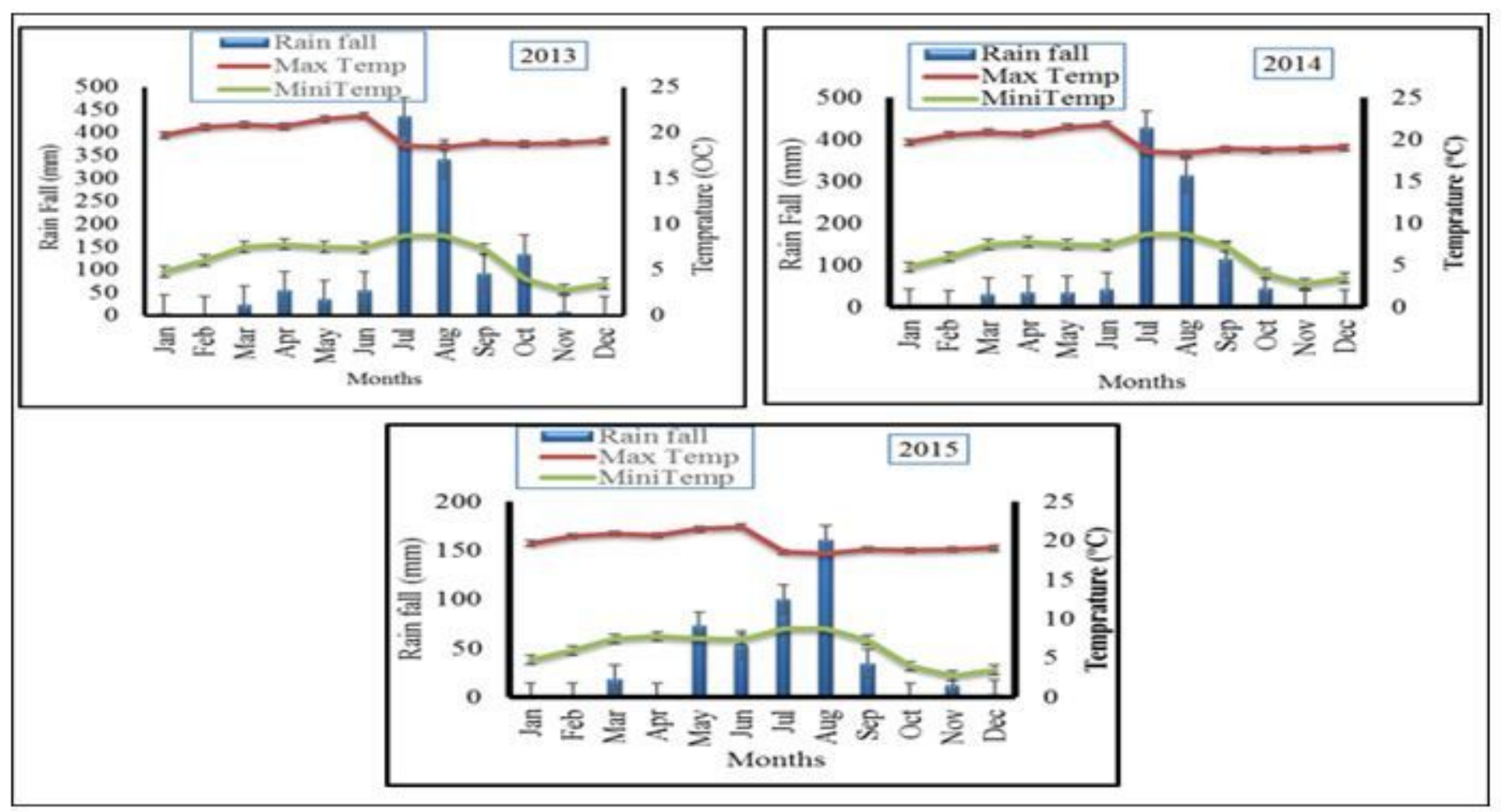

Figure 1

Monthly rain fall and average maximum and minimum temperatures in the three years of the study district 


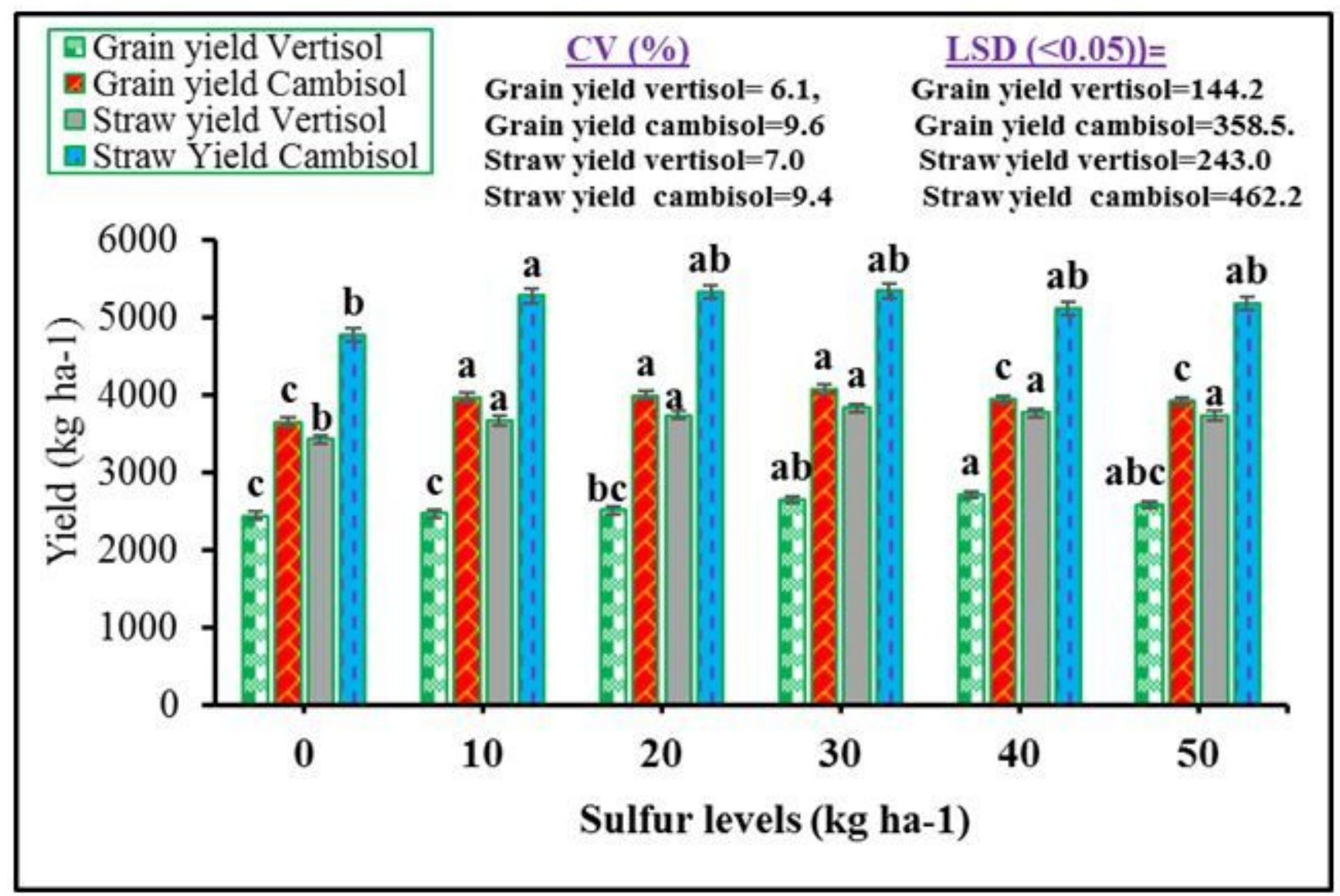

Figure 2

Effect of S on mean yield of Wheat on Vertisols and Cambisols of Basona worena District. 